\title{
ENVIRONMENTAL VARIABLES AND FISHERIES DIVERSITY OF THE NUWA RIVER, PANCHTHAR, NEPAL
}

\author{
Jash Hang Limbu* and Archana Prasad* \\ *Central Department of Zoology, Tribhuvan University, Kirtipur, Kathmandu, Nepal.
}

\begin{abstract}
The fish samples were collected from October 2017 to June 2018 in Nuwa River from four sampling stations by using cast net, bamboo fish trap and mosquito nets. Environmental parameters: water temperature, dissolved Oxygen (DO), $\mathrm{CO}_{2}, \mathrm{pH}$, hardness and water velocity were analyzed during each field visit. Eight fish species were collected in present study. The most copious species were Schizothorax plagiostomus, and Schistura multifaciatus. Shannon-Weiner fish diversity index and species richness recorded were highest at station I and lowest at station III, similarly, evenness index was highest at station I and lowest at station III. The water volume, water depth, and the availability of substrates were found to be major influential factors for the weight and length of the fishes. The redundancy analysis (RDA) portrayed that environmental variables like dissolved oxygen, free- carbon dioxide, and $\mathrm{pH}$ were found to be pivotal variables to shape the fish assemblage structure of Nuwa River. The cluster analysis delineated that similarity between fish species subsided as the distance of sites turgid.
\end{abstract}

Keywords: Nuwa river; Stream; Fish diversity; RDA; Cluster analysis; Panchthar; Nepal.

\section{INTRODUCTION}

The richness and uniqueness of the fresh water fishes of Nepal are due to different topographic and climatic conditions of the country within a short distance of elevation from plain Terai to high altitude mountains as well as from tropical to alpine climatic conditions ${ }^{20}$. Nepal is endowed with many forms of water resources like of rivers, streams, lakes, reservoirs, ponds, swamps, and paddy fields scattered throughout the country. Rivers are the most important which represents $49 \%$ of the total water body ${ }^{24}$. Nepal is rich in water and fish resources but, study on fish diversity is few. Some national and international researchers have done painstaking research work regarding the fish diversity of $\mathrm{Nepal}^{19}$ recorded 182 fish species, ${ }^{15}$ recorded 187 fish species while ${ }^{21}$ recorded 199 fish species and recorded 232 fish recorded from Nepal. Similarly, ${ }^{20}$ has reported 228 fish species from Nepal. Recently, ${ }^{7}$ have reported 151 fish species from eastern Nepal.

Some international ichthyologist have given outstanding contribution regarding the fishes of Nepal, for instance; ${ }^{2,3,26}$ did pioneer research work on fishes in different river system of Nepal.

Panchthar district lies in middle hills region of eastern Nepal. The major rivers of Panchthar district are Tamor, Hima, Ima, Namdu, Nuwa, Kabeli, and Nibhu rivers. The Nuwa River is situated in the southern part of the district and surges westwards to join the Tamor River. The water of Nuwa River is used for irrigation, drinking water supply, micro- hydropower generation, and water mills. Eastern Nepal is rich in water resources but, study on fish diversity is scanty. Very few research works have been carried out in eastern Nepal Rivers. For instance; 8,9,10,11,18,21,23 deserves special mention. It is believed that there are lots of rivers are still unexplored in the eastern Nepal.

\section{MATERIALS AND METHODS}

\section{Study area}

The Nuwa River is perennial and torrential river which originates from Kurumba. The water is crystal clear except during the rainy season. Due to a steep gradient upstream, its water velocity is higher than in the plains area downstream.

\section{Sampling stations and time schedule of the study}

To study the fishes, four permanent sampling stations were established: Sangengwa (26.903966N, 87.660082E), Thamthum $(26.903966 \mathrm{~N}, 87.653635 \mathrm{E})$, Arubote $(26.903478 \mathrm{~N}, 87.647106 \mathrm{E})$, and Limba $(26.903214 \mathrm{~N}$, $87.637600 \mathrm{E})$. The river beds were strewn with boulder, cobbles, pebbles, gravels, and sand. Sampling stations were categorized on the basis of different features such as human intervention area, water current, disturbed and undisturbed area etc. Station I (Sangengwa) was chosen in the undisturbed area and it had got the big boulders, very little gravels and sand. Whereas station II (Thamthum) and station III (Arubote) were selected in human intervention area. These two stations were strewn with the cobbles, pebbles, gravels, and sand. But the station III was selected in the highly affected by human activities (like grazing their cows, cattle, electro-fishing etc.) as compared to the station II. Similarly, station IV (Limba) was selected at the confluence spot, here another Mawa River joins with Nuwa River, and it consists of cobbles, pebbles, gravels, and sand. The field study was started conducted from 15 October, 2017 - 20 June, 2018 to cover four seasons Autumn (October), Winter (January), Spring (April) and Summer (June).

\section{Fish sampling}

The fish collection was done with the help of local fisherman by using cast net, bamboo fish trap and mosquito nets. Cast net of $6 \mathrm{~mm} \times 6 \mathrm{~mm}$ mesh size was used for the collection of fishes. Fish sampling was done

Author for Correspondence: Archana Prasad, Central Department of Zoology, Tribhuvan University., Kathmandu, Nepal.

E-mail: archanaprasad001@gmail.com 
at 7 am to 11 am in every station. Habitat and morphological characters of fishes were recorded at the time of collection. Before preservation, collected fishes were photographed with Nikon Digital Camera and preserved in $10 \%$ formalin solution for further study. Specimens were taken to the laboratory of the Central Department of Zoology (CDZ) for identification. Total length $(\mathrm{cm})$ and the weight $(\mathrm{gm})$ of the collected fishes were measured throughout the study period. The identification was done with the help of taxonomic references ${ }^{25,4}$ to the species level.

\section{Environmental variables}

The following environmental parameters were analyzed on the spot during each field visit: water temperature, dissolved Oxygen (DO), $\mathrm{CO}_{2}, \quad \mathrm{pH}$, hardness and water velocity. Water temperature $\left({ }^{\circ} \mathrm{C}\right)$ was measured with a digital thermometer by placing it in the water at a depth of 1 feet. DO (mg/l) was measured by the Winkler titra-metric method. $\mathrm{pH}$ was measured by using a $\mathrm{pH}$ meter (HI 98107, HANNA Instrument). Total hardness $(\mathrm{mg} / \mathrm{l})$ was determined by using EDTA titrametric method. Total alkanity $(\mathrm{mg} / \mathrm{l})$ was determined by titration method, using indicators such as phenolphthalein and methyl orange. Water velocity was measured by the float method with the help of a stop watch and measuring tape.

\section{Statistical analysis}

Fish species were analyzed into different assemblage clusters based upon abundance utilizing pvclust package in R. Fish species, seasons and environmental variables were analyzed through multivariate analysis tool. Detrended correspondence analysis (DCA; Hill \& Gauch, 1980) was done to determine whether redundancy analysis (RDA), or canonical correspondence analysis (CCA) would be the most appropriate model to describe the association between species abundance, seasons and environmental variables. Therefore, a direct multivariate ordination method ${ }^{26}$ based on a linear response of species to environmental gradients was applied by using vegan library in " $R$ " 13 .

\section{METHODOLOGY}

A total of eight species were collected, belonging to one order, two familes and three genera Table-1). Nemachailids were the dominant group (62.5\%) followed by Cyprinids (37.5\%) (Fig.1). However, Schizothorax plagiostomus was found to be most pre- dominant species. The highest diversity index was found in station I and lowest in station III.

Table 1. Fishes collected from Nuwa River

\begin{tabular}{|c|c|c|c|c|}
\hline S.No. & Order & Family & Scientific Name & Vernacular name \\
\hline \multirow[t]{8}{*}{1.} & \multirow[t]{8}{*}{ Cypriniformes } & \multirow[t]{3}{*}{ Cyprinidae } & Schizothorax plagiostomus (Heckel, 1877) & Asala \\
\hline & & & $\begin{array}{l}\text { Puntius sophore (Hamilton-Buchanan, } \\
\text { 1822) }\end{array}$ & Sidhre \\
\hline & & & $\begin{array}{l}\text { Neolissochilus hexagonolepis (McClelland, } \\
\text { 1839) }\end{array}$ & Katlae \\
\hline & & \multirow[t]{5}{*}{ Nemacheilidae } & Schistura multifaciatus (Day, 1878) & Gadela \\
\hline & & & Schistura rupecula (McClelland, 1838) & Bhotee gadelo \\
\hline & & & Schistura scaturigina (McClelland, 1839) & Gadela \\
\hline & & & Schistura himachalensis (Menn. 1987) & Gadela \\
\hline & & & Schistura horai (Menon, 1951) & Suli Gadela \\
\hline
\end{tabular}

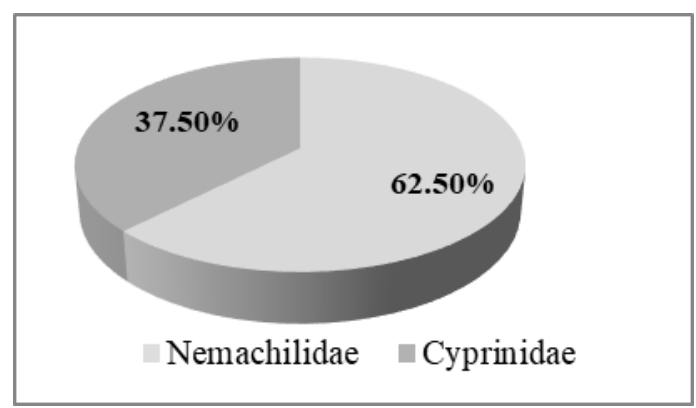

Figure 1. Family-wise percentage composition of fishes

\section{Environmental variables}

Dissolved oxygen concentration was found in this study ranged between $6-11.5 \mathrm{mg} / \mathrm{L}$ and almost same value was reported $b y^{21}$ from Tamor River. The $\mathrm{pH}$ value of present study ranged from 7-9 and water temperature from $8^{\circ} \mathrm{C}$ $24^{\circ} \mathrm{C}$. Hardness of water was found in between $60-90$ $\mathrm{mg} / \mathrm{L}$. Velocity of water ranged in between 0.4 to 1 meter per second (Table 2). 
Table 2: Observed environmental variables of the present study area.

\begin{tabular}{|c|c|c|c|c|c|c|c|}
\hline Site & Season & $\begin{array}{c}\text { Dissolved } \\
\text { oxygen(mg/l) }\end{array}$ & pH & $\begin{array}{c}\text { Free carbon } \\
\text { dioxide } \\
(\mathrm{mg} / \mathrm{l})\end{array}$ & $\begin{array}{c}\text { Water } \\
\text { velocity } \\
(\mathrm{m} / \mathrm{sec})\end{array}$ & $\begin{array}{c}\text { Water } \\
\text { temperature } \\
\left(C^{\mathbf{0}}\right)\end{array}$ & $\begin{array}{c}\text { Total } \\
\text { hardness } \\
(\mathrm{mg} / \mathrm{l})\end{array}$ \\
\hline A & Winter & 11.5 & 7 & 5 & 0.55 & 8 & 75 \\
\hline $\mathrm{B}$ & Winter & 8 & 8 & 6 & 0.5 & 8.5 & 80 \\
\hline $\mathrm{C}$ & Winter & 6 & 7.9 & 8 & 0.4 & 11 & 87 \\
\hline $\mathrm{D}$ & Winter & 8 & 7.6 & 5.5 & 0.75 & 13 & 70 \\
\hline $\mathrm{A}$ & Spring & 9 & 8 & 5.5 & 0.65 & 9 & 80 \\
\hline $\mathrm{B}$ & Spring & 7.5 & 7.9 & 8 & 0.6 & 14 & 82 \\
\hline $\mathrm{C}$ & Spring & 6 & 8 & 7.7 & 0.58 & 19.5 & 77 \\
\hline $\mathrm{D}$ & Spring & 8 & 7.7 & 7.8 & 0.95 & 17.6 & 77 \\
\hline $\mathrm{A}$ & Summer & 8 & 7.6 & 7 & 0.68 & 14 & 88 \\
\hline $\mathrm{B}$ & Summer & 8 & 7.8 & 9 & 0.55 & 16 & 90 \\
\hline $\mathrm{C}$ & Summer & 7 & 6.9 & 7.5 & 0.5 & 22 & 89 \\
\hline $\mathrm{D}$ & Summer & 7.5 & 7.8 & 7.6 & 0.75 & 24 & 90 \\
\hline $\mathrm{A}$ & Autumn & 10.5 & 7.6 & 5.7 & 0.54 & 11 & 78 \\
\hline $\mathrm{B}$ & Autumn & 9 & 8 & 7 & 0.56 & 17 & 90 \\
\hline $\mathrm{C}$ & Autumn & 6.5 & 9 & 6.8 & 0.6 & 22 & 88 \\
\hline $\mathrm{D}$ & Autumn & 10 & 7.6 & 6 & 1 & 14 & 90 \\
\hline
\end{tabular}

A maximum of $15 \mathrm{~cm}$ and a minimum of $5 \mathrm{~cm}$ in length; and maximum $36 \mathrm{gm}$ and minimum of $4 \mathrm{gm}$ in weight of fishes were found (Table 3).

Table 3: Observed length and weight of fishes of the present study area.

\begin{tabular}{|l|c|c|}
\hline Name of the fishes & Length of the fishes (cm) & Weight of the fishes (gm) \\
\hline Schizothorax plagiostomus (Heckel, 1877) & $9-18$ & $4-36$ \\
\hline Punius sophore (Hamilton-Buchanan, 1822) & $7-11$ & $10-13$ \\
\hline Neolissochilus hexagonolepis (McClelland, 1839) & $12-15$ & $3-5$ \\
\hline Schistura multifaciatus (Day, 1878) & $5-9$ & $4-6$ \\
\hline Schistura rupecula (McClelland, 1838) & $6-8$ & $4-5$ \\
\hline Schistura scaturigina (McClelland, 1839) & $6-9$ & $2-3$ \\
\hline Schistura himachalensis (Menn. 1987) & $3-3.8$ & $2-3$ \\
\hline Schistura horai (Menon, 1951) & $3-4$ & \\
\hline
\end{tabular}

\section{Shannon-Wiener index}

The highest Shannon-Weiner fish diversity index was found in January (1.69) and the lowest in July(1.43). The highest Shannon-Weiner diversity index was found in station I (1.43) and lowest (0) was found in station III. Though, no significant difference was found in the mean of Shannon-Weiner diversity index among the months and stations except station III. The diversity index of station III was zero might be due to illegal electro fishing, using different poison herbs and diversion of water which was confirmed by interviewing more than one dozen of local people.

\section{Margalef's species richness}

The species richness in four sampling stations showed considerable variation and highest species richness was found in July (3.31) and lowest in April (2.87). Station I showed the highest species richness index (5) whereas station III showed zero. Species richness index of station III was zero, it might be due to illegal electro fishing, using different poison herbs and diversion of water etc.

\section{Pielou's evenness index}

The evenness index was varied from 0.74 to 0.92 , the highest evenness index (0.92) was found in April and lowest (0.74) was found in July. For stations, evenness index was varied from 0 to 0.38 , the highest evenness index (0.31) was found in station I and lowest (0) was found in station III. 


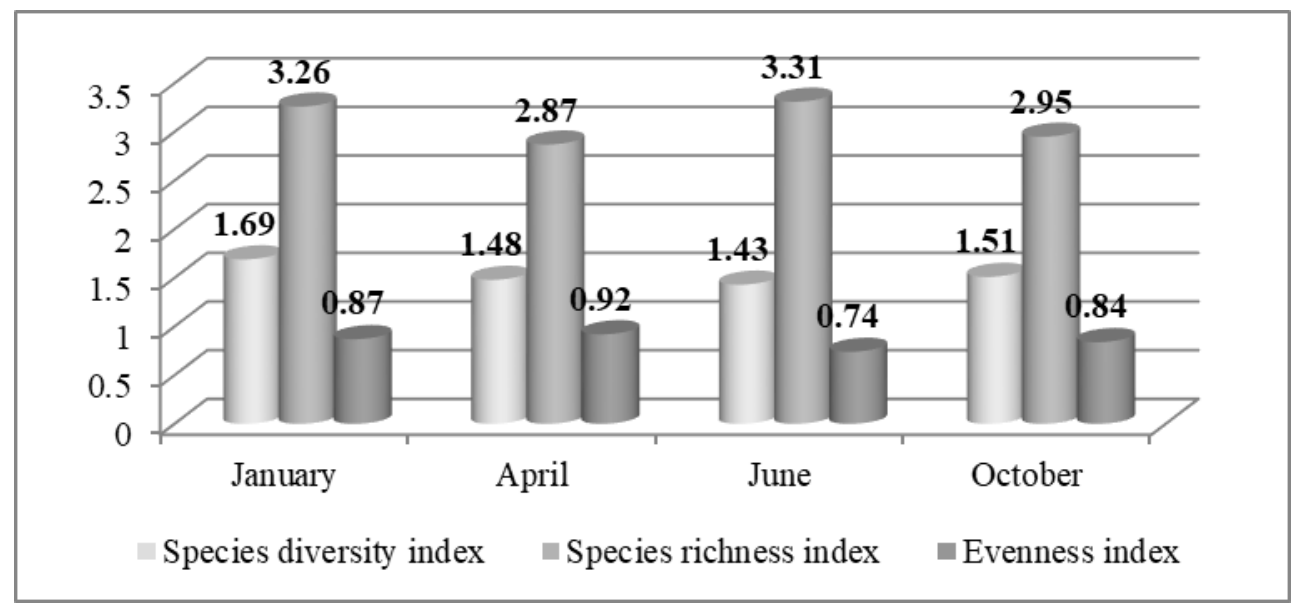

Fig. 2: Month wise diversity index, species richness index and evenness index

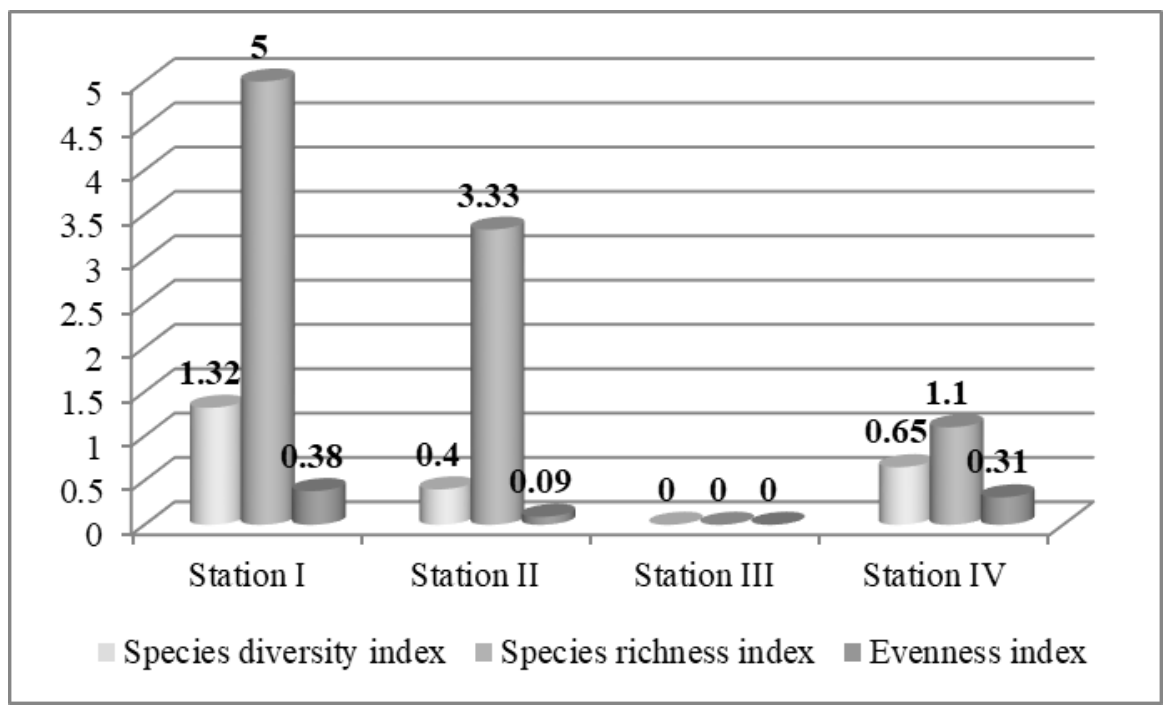

Fig.3: Station wise diversity index, species richness index and evenness index

Species, seasons and environmental variables between dissolved oxygen and Schistura scaturigina. relationships

Free carbon-dioxide, $\mathrm{pH}$ and month of June showed positive correlation. In contrary, water temperature,

The values of axis length and eigen values obtained from DCA suggest that the linear model associated with RDA was more applicable. The redundancy analysis (RDA) velocity, total hardness showed positive relationship in October (Fig.4). portrays that there was a strong positive correlation

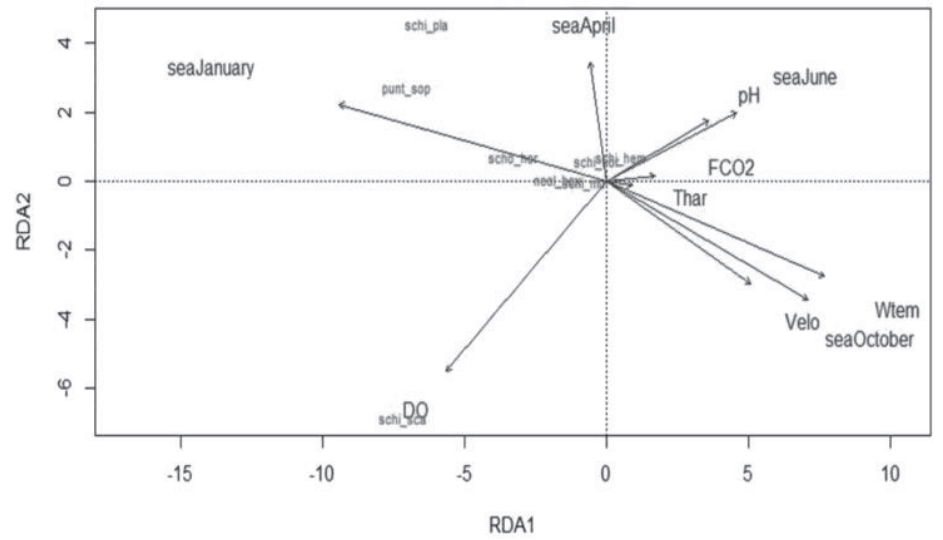

Fig 4: Redundancy analysis (RDA) ordination showing fish species in relation to seasons and environmental variables in the Nuwa River $\left(\right.$ sea $=$ season, $\mathrm{DO}=$ dissolved oxygen, $\mathrm{f}_{\mathrm{C}_{2}}=$ free carbon-dioxide, Velo $=$ velocity, $\mathrm{W}_{\text {temp }}=$ water temperature, $\mathrm{T}_{\text {har }}=$ total hardness. 


\section{pvCluster analysis of fish species}

The pvcluster analysis of fish species generated a dendrogram with two main clusters or edge numbers. One of the main group was formed at the right end of the plot with two subgroup clusters; 1, 2 and 3,4. 1 and 2 clusters delineate significant cluster, in contrary 3 and 4 clusters showed insignificant. In cluster 6 , there is no significant relation between them and also shows no significant relation with other cluster groups (Fig. 5).

Cluster dendrogram with AU/BP values (\%)

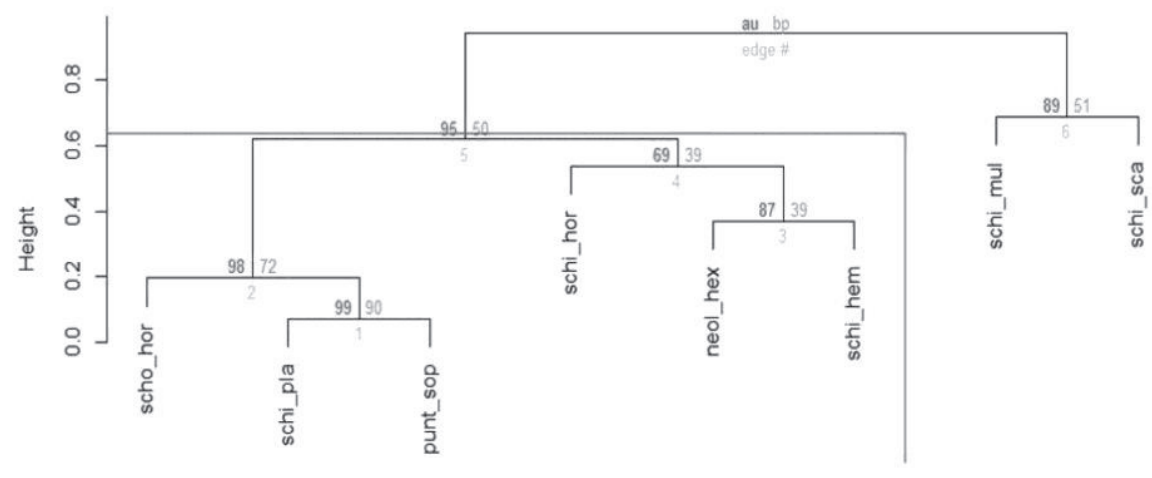

Distance: correlation

Cluster method: average

Fig 5: Dendrogram of cluster analysis comparing fish species on the basis of fish assemblage.

(schi_hor = Schistura horai, Schi_pla = Schizothorax plagiostomus, punt_sop = Puntius sophore, schi_him =Schistura himachalensis, schi_sca $=$ Schistura scaturigina, schi_mul $=$ Schistura multifaciatus, schi_rup $=$ Schistura rupecula, neo_hex $=$ Neolissochilus hexagonolepis

\section{DISCUSSION}

In the present study, single order (Cypriniformes) comprising two families (Cyprinidae with 3 species and Nemacheilidae with 5 species) was found with cypriniformes as dominant which is consistent with the findings of ${ }^{2,11,14}$. A total of eight fish, species were recorded during $\mathrm{m}$ study. Among them Schistura multifaciatus and Schizothorax plagiostomus were the most abundant species. On the other hand, most studies showed that the Cyprinidae was the dominant family ${ }^{5,9,10,21,22,23}$ have recorded the dominant family. But the present work has got a Nemachailidae as the dominant family. Dissolved oxygen concentration was found in this study ranged between $6-11.5 \mathrm{mg} / \mathrm{L}$ and almost same value was reported by ${ }^{21}$ from Tamor River. The present work of $\mathrm{pH}$ value showed quite high (7-9) is due to extreme human interferences with domestic waste disposal, different stupefied poison herbs, and different chemicals Water temperature was higher $\left(8^{\circ} \mathrm{C}-24^{\circ} \mathrm{C}\right)$ then reported by ${ }^{21}$. According to communication with local fisherman and community, some fishes of Nuwa River has not been found since last 15 years, like Aanguila, catla, and Semiplotus may be due to irrigation, expansion of micro-hydropower, water mills. The values obtained for the Shannon-Weiner diversity index was not high may be due selectivity effect of fishing gears ${ }^{6}$. The highest Shannon-Weiner diversity index (1.32) was found in station I and January month (1.69) whereas, lowest value (0) was observed at station III and during July. The result of this study is strongly correlated with the results of ${ }^{12}$. In each case high Shannon diversity index is involved with low individuals and low diversity involved with high number of individuals. The differences occurring in the biodiversity indexes may be due to atmospheric air currents and environmental conditions ${ }^{6}$, and seasonal fish migrations ${ }^{16}$. At station III, the diversity index was zero because fish was not found throughout the year; this might be due to illegal electro fishing, extreme human interference with domestic waste disposal, using different stupefied poison herbs and diversion of water $^{6}$ as per the communication with the local people and fisherman. Major threats can be classified into overexploitation, water pollution, flow modification, destruction of habitat and invasion by exotic species ${ }^{1}$.

\section{CONCLUSION}

A total of eight species were collected, belonging to Cypriniformes with Nemachailids as dominant group $(62.5 \%)$ followed by the Cyprinids $(37.5 \%)$. The fish diversity of Nuwa River is declining with the disappearance of Aanguila, catla, and Semiplotus. This is due to extreme human interference activities with domestic waste disposal, using different stupefied poison herbs, chemicals, water diversion, and electrofishing activities as it was clearly seen in station III. The water volume, water depth, and the availability of substrates were found as major influential factors for length and weight of the fishes.

\section{ACKNOWLEDGEMENT}

We are very thankful to Mr. Samir Rai for fish collection during the whole study period. Our special thanks go to Dr. David R. Edds for checking the initial manuscript, and providing input to improve the paper, Department of Biological Science, Emporia State University. We are also thankful to Suman Rai, Chhavi Limbu, Razina Limbu, Kumar Biswakarma, Nar Bahadhur Youngyang, Aindra Idingo, Hasta Bahadhur Limbu and Kangaroti 
Limbu for their valuable suggestions. We would like to thank Central Department of Zoology for laboratory facility.

\section{REFRENCES}

1. Dudgeon, D., Arthigton, AH., Gessner, MO., Kawabata, ZI., Knowler, DJ., Leveque, C., Naiman, RJ., PrieurRichard, AH., Soto, D and Stiassny, ML. 2006. Freshwater biodiversity: importance, threats. Status and conservation challenges. Boil. Rev. 81:163-182.

2. Edds, DR. 1986. Fishes of Klai Gnagaki/Narayani Rivers, Nepal. Journal of Natural History Museum, Tribhuvan University, Kathmandu. 10(14): 14-22.

3. Hamilton, FB. 1822. An account of the fishes found in the river Ganges and its branches. Printed for A. Constable and Company. pp. 7405.

4. Jayaram, KC. 2010. The freshwater fishes of Indian region. Narendra Publishing House, Delhi, India. pp. 614.

5. Joshi, D and KC, B. 2017. Fish Diversity of Ghodaghodi Lake in Kailali, Far- West Nepal. 22(1): 120-126.

6. Keskin, C and Unsal, N. 1998. The Fish Fauna of Gokceada Island, NEAegean sea. Turkey. Italian Journal of Zoology. 65 299-302.

7. Limbu, J.H, Baniya, C.B and Prasad, A. 2019. Spatio-Temporal Variation of Fish Assemblages in Ratuwa River, Ilam, Nepal. J Ecol \& Nat Resources. 3(3): 000168.

8. Limbu, J.H and Gupta, S. Fish diversity of Damak and lower Terai region of Ratuwa River of Jhapa district, Nepal. International Journal of Fauna and Biological studies 2019. 6(1): 01-04.

9. Limbu, J.H, Chapagain, N., Gupta, K.S and Sunuwar, S. 2019 Review on fish diversity of eastern Nepal. International Journal of Fisheries and Aquatic Studies 2019. 7(3): 177-181.

10. Limbu, J.H, Prasad, A and Shrestha, Ohm. Ichthyofaunal diversity of Bakraha River of Morang district, Nepal. International Journal of Fisheries and Aquatic Studies 2018. 6(5): 267-271

11. Limbu, J.H., Acharya, G.S and Shrestha, OmH. 2016. Ichthyofaunal diversity Dewmai Khola of Ilam district. Thesis (Bachelor's degree), T.U., Kathmandu, Nepal.

12. Mishra, A.R., and Bniya, C.B. 2016. Ichthyofaunal Diversity and Physico- chemical Factors of Melamchi River, Sindhupalchok, Nepal. Vol 21(1), 10-18.

13. Oksanen J, Blanchet .FG, Kindt R, Legendre P, Minchin P.R, Ohara R.B, Simpson G.L, Solymos P, Henry M, Stevens H, et al.
2019. Vegan: Community ecology package. $R$ package version 2.3-1. Available from: http: CRAN.R-project.org/package=vegan .

14. Pokharel, K.K. 1999. Fish Biodiversity of Lakes in Pokhara Valley and need of their Conservation. In Proceeding of IIIrd National Conference on Science and Technology, 1999.

15. Rajbanshi, K.G. 2005. Review on current taxonomic status and diversity of fishes in Nepal. Academy of Science and Technology. Occasional paper No. 10: pp.41.

16. Ryer, C.H and Orth, R.J. 1987. Feeding ecology of the Northern pipefishSyngnathus fuscus, in a Seagrass community of the lower Chesakpeake bay. Estuaries. 10(4): 330-336.

17. Saund, T.B and Shrestha, J. 2007. Fish and benthic fauna in Kulekhani reservoir. Nepal Journal of Science and Technology. 8: 63-68.

18. Shah, P. 2016. Study of the freshwater fish diversity of Koshi river of Nepal. International Journal of Fauna and Biological Studies. 3(4): 78-81.

19. Shrestha, J. 2001. Taxonomic revision of fishes of Nepal. In: Biodiversity, agriculture and pollution in South Asia. (Eds. P.K. Jha et al.) ECOS, Kathmandu. pp. 171-180.

20. Shrestha, J. 2013. Biodiversity of fish speared in (biological diversity and conservation). Nepal Academy of Science and technology (NAST) Kathmandu, Nepal. Nepalpedia series No.2.

21. Shrestha, J., Singh, D.M and Saund, T.B. 2009. Fish diversity of Tamor River and its major tributaries of eastern Himalayan region of Nepal. Nepal Journal of Science and Technology. 10: 219-223.

22. Shrestha, J.N. 2016. Fish diversity of Triyuga River, Udayapur District, Our Nature. 14 (1): 124-134. DOI: htt://dx.doi.org/10.3126/on.v14il.16452.

23. Subba, BR., Pokharel, N and Pandey, M.R. 2017. Ichthyofaunal diversity of Morang district, Nepal. Our Nature. 15(1-2): 55-67. DOI: htt:/dx.doi.org/10.3126/on.v15il-2. 18794.

24. Swar, D.B. 2002. The status of coldwater fishes and fisheries in Nepal and prospects of their utilization for poverty reduction. FAO fish. Tech, 143

25. Talwar, P.K and Jhingram, A.G. 1991. Inland fishes of Indai and Adjacent countries. Volume I and II. Oxford and IBH Publishing Co. India. pp. 1158

26. Ter Break CJF. 1988a. CANOCO: A FORTRAN Program for canonical community ordination by (partial) (detrnded) (Canonical) correspondence analysis, principle component analysis and redundancy analysis (Version 2.1). Washington: Agricultural Mathematics Group. (Report LWA-88-02).

27. Terashima, A. 1984. Three new species of the cyprinid genus Schizothorax from Lake Rara, North-West, Nepal. Japanese Journal of Ichthyology. 31(2): 122-135. 